\title{
Environment Impact of Ex-Industrial Areas in Laç and Rubik and the Possibilities for Their Functional Transformation- a Comparative Analysis
}

\author{
Xhilda Dedaj MSc \\ ., University of Tirana \\ Prof. as. Dr. Sonila Papathimiu \\ University of Tirana
}

\begin{abstract}
Industrial areas in Albania have had an important role for many years during the communist regime, but their industrial function declined after the 1990s. This study focuses on the industrial areas of Laç and Rubik, two small towns in Albania. The closing of some industrial activities in these towns has increased environmental pollution and health issues of their inhabitants due to the release of toxic substances in the territory. There were chosen these two towns to compare because: First, they are near each other and are part of the same District of Lezha; Second, they both are two ex-industrial towns which were created by the establishment of the industry, former Chemical and Metallurgical Combine in Laç and former Copper Plant in Rubik; third, in both towns the industry has caused environmental pollution in their vicinity, but mostly on the waters of Mat river; fourth, after the year 1990, when the industry that created them has stopped functioning, they have good possibilities to develop religious tourism. In both towns are two important and much-visited churches: the Church of St. Ndout, Laç and the Church of Shelbuemi in Rubik. Another reason is the lack of studies for the ex-industrial areas in Albania, especially for Laç and Rubik. The main aim of this study is to identify and assess the levels of pollution caused by ex-industrial building (actually not functioning) on land, air, water, and human health and to find the best way for their effective reuse and functional transformation.
\end{abstract}

Keywords: ex-industrial areas, environmental pollution, reuse, functional transformation

\section{Introduction}

Kurbini and Mirdita Municipality are part of Lezha District (Map 1). Kurbini Municipality has four administrative units where Laçi is the main town (Map 2), and Mirdita Municipality has six administrative units with main town Rrëshen (Map 3). The territory of Kurbini extends into two physiographic regions: in the Central Mountainous region and Western Lowland, and it has a very favorable position related to the main roads in Albania and the capital city. Also, the geographical position of Mirdita is very strategic and advantageous for its development. In both directions, the Great and Small Fan River valleys connect the Western Lowland with Kukës and the tectonic fracture Mallë Lurë-Urakë connects the Black Drin River with the hollow of Mati.

This paper analyses the industrial development of Laçi and Rubik during the communist regime (1945-1990) and after it (1990 and actually). Some of the advantages of these towns for the development of the industry during the communist regime were:

Firstly: Laçi is near to two important ports, port of Durrës which is the largest and most important in Albania and port of Shëngjin a smaller one, but important for the import-export activity. During communist regime and actually, most of the machinery, industrial equipment, raw and finished materials are imported/exported through these two ports and port of Vlora, which is a little farther to these towns.

Secondly: Both Rubiku and Laçi town were very close to the raw material sources (copper) found mainly in the northeastern part of the country, which supplied the Copper Plant in Rubik and the Pyrometallurgy Plant within the Chemical and Metallurgical Combine in Laç. 
Third: Laçi town had an optimal position being very near to the main national road and railway of Albania (The road and railway infrastructure in Albania during the communist regime was very poor and sometimes in very bad condition), while, Rubik was far from these roads, and only after the establishment of industry were constructed some secondary roads and railways to shorten the distances.

Fourth: Rubik and Laçi were close to potential customers for agriculture supplies, providing chemicals and pesticides, and for the copper manufacturers, especially for the copper wire plant in Shkodra which is $57 \mathrm{~km}$ from Laçi and $71 \mathrm{~km}$ from Rubik.

Fifth: Both towns were very close (no more than $30 \mathrm{~km}$ ) to two important hydropower plants (Ulza and Shkopet built on Mat River), which provided energy for the industry. The waters of Mati River were used for the production processes in the industry but also for the inhabitants of the two towns which were growing and expanding after the establishment of industrial facilities (Laçi, 2008).

Sixth: Government policy during the communist regime was an important locational factor, which affected many decisions for the industrial factories with the main objective to distribute them all over the country even though some factors were not profitable.

\section{Main Factors For The Localization Of Industry In Laç And Rubik}

Albania, during the communist regime, had a centralized state economy with no possibilities for the free initiative. The level of decentralization was very low or almost inexistent and in some cases punishable. The main factor for the localization of every industrial factory, mine opening, industrial combine, hydropower plants, etc., was political. The former communist government of Albania aimed to industrialize the country and to provide equitable distribution of the industry. Although the main factor was political and in many cases resulted not profitable for the economy, other factors influenced the localization of the industry in Laç and Rubik (our study cases).

\section{I.a. Natural Factors}

The geological composition was an important factor for the localization of copper mine in Rubik. This area has mostly magmatic rocks (infusive and effusive) rich with two kinds of copper ores: hydrothermal and quartz-sulfuric. The hydrothermal ore (chalcopyrite) are in the peripheral areas of Mirdita tectonic zone, where is Rubiku (Map 4.). The quartzsulfur minerals are mostly in Kurbnesh and Thirrë. In Laç, the geological construction was not favorable for the location of the industry. The Chemical Metallurgical in Laç was on collusive and proliferative deposits and sloping materials which were highly unstable and endangered by the erosion.

The raw material was the main factor for the localization of the Copper Smelting Plant in Rubik near the copper mine. The lost of minerals and transportation costs were minimal in this case. The copper sources and mines which supplied Rubiku Copper Plant were in Perlati, Kurbneshi, Repsi, Rubiku, Kulmja, Spaçi, all villages of Mirdita (Map 4.). The raw material was an important factor especially for the Pyrometallurgical plant in Laç, which was supplied with copper powder by the Copper Plant in Rubik (distance Laç to Rubik is only $16 \mathrm{~km}$ ).

Climate, as a locational factor is important because it affects not only the development of industry and other economic activities but has a direct impact on the physical and mental health of workers. In both towns, the climate conditions with annual average temperatures of January from $4^{\circ} \mathrm{C}$ to $5.5^{\circ} \mathrm{C}$ and of July from $23.2^{\circ} \mathrm{C}$ to $25^{\circ} \mathrm{C}$, the precipitation from $1100 \mathrm{~mm}$ in Lacc and $1800 \mathrm{~mm}$ in Rubik were favorable for the development of the industry.

Hydrography of Rubiku and Lacci is very rich in surface and underground waters which have supported the development of the industry. The main water source is Mati River, which is used not only for the industry but also for power production, urban use and irrigation of agricultural land. The Fushë Miloti and Fushë Kuqe areas in Kurbini Municipality are very rich with underground water, which has been used to supply water for the industry in Laç and for agriculture with pumping stations, drainage canals and wells opened during the communist regime.

Land and soil are also important for the location of industry. During the communist regime, the land was state property, so its price was not a locational factor. In Laç and Rubik the disponibility of land was not favorable for the development of industry because in Laç the industrial plants and factories were constructed on agricultural land, which is not recommended and in Rubik in a not stable land (only $5 \mathrm{~m}$ above river level). 


\section{I.b. Social and economic factors}

The social and economic factors are very important in the location of industry. Nowadays with the technology advancement in every economic sector, some of the natural factors are losing importance and instead are gaining the human factors such as labor force price, capital, government policies, market, etc. These factors are influencing the distribution of industry around the world and also in Albania. How were these factors when the industry established in Lacc and Rubik? Were all of them very favorable and profitable or the state had to invest in them?

The government policy, as we mentioned above, was the main factor for the location of industry in Lacc and Rubik as in every part of Albania. Considering this, although some other factors were not very profitable the industry still developed in Lacc and Rubik.

The capital for the development of industry also was state property which was the only one to decide where and in what to invest. All the investments in Lacc and Rubik were from the state capital, and although in the first years the industry was not very profitable they continued functioning. Many investments were made for the opening of mines, construction of industrial buildings, roads, railways, water supplies, residents for the workers and their families, etc.

The labor force was both positive and negative factor for the industry in Lacc and Rubik. The price of the labor force was a positive locational factor as the salaries were uniform in all country and established by the government, but the disponibility of the labor force was negative because both areas were not much populated. The state invested to bring the labor force in these towns and to provide everything for their living. These investments increased the cost of developing industry in these areas. In the Copper Plant in Rubik were employed 700 workers (information from the interviews with engineers of Copper plant in Rubik) and $80 \%$ of them were from the other villages of Mirdita which later lived in Rubik while in Laç were almost 1300 workers from near areas and engineers from the capital city which were brought to live and work. Many investments were also made for the security of work, especially in the Chemical Metallurgical Combine in Laç, which was one of the most saved in Albania. The workers had special clothes to protect them from asbestos, gas masks, clothes to protect them from high temperatures, acids, and fire. The accidents on work were rare but not fatal for people. The aspiration system was very good, and every worker had its garderobe and had access to the mensa and the showers in the Combine. The qualification of the population was another factor which in Lacc and Rubik was not favorable as the local population education level was very low. The extraction sector had no specific requirements for the level of education, but other factories needed chemists, metallurgist and different engineers (chemical, electric, construction, mechanical engineers), etc. They were all brought from other Albanian towns and cities, and for the future generation, the state invested in opening professional schools in Laç and Rubik. The salaries were very good compared with other professions and varied from $500 \mathrm{ALL}$ ( an acronym for Albanian Lek) to $700 \mathrm{ALL}$ (information from engineers who have worked in the industry) when an average worker in construction in that period was paid around $200 \mathrm{ALL}$.

The market was another locational factor which was decided by the central government. Most of the copper produced in Rubik (almost 80\% of the production) was sent to the Copper Wire plant in Shkodra which produced for the inner and outer market high-quality products. The copper not used in this plant was also exported as cathode copper with a purity of $99.99 \%$. The market was not a direct factor for the localization of the industry in the studied towns, but their vicinity with the ports and other industrial factories was a favorable factor. The copper and its products were exported mostly to Russia, China, Turkey, etc.

Transportation was not favorable for the establishment of the industry in Rubik but was favorable in Laç, which was near the national road and the only railway of Albania. Although the state invested in roads, railways and cable car for the transportation of copper from the mines to the Smelting Plant, there were many difficulties in distributing on time the raw material. The roads were not in very good condition, some of them had many curves, the number of trucks was low, and sometimes they were in bad conditions losing part of the weight on the road.

\section{The Impact Of Industry On Population And Urbanization Of Laçi And Rubik In The Period 1945-1990}

Albania is very rich in mineral resources, although it is a small country. Most of the mineral reserves were discovered by foreign researchers, especially Italians. Albania was very poor before and after the Second World War, and it lacked 
qualified researchers, equipment, and money to support the exploration of minerals and extraction industry, although the presence of copper in Rubik has been detected from antiquity.

The first to extract copper in Rubik were some Italian mining firms, which built the first nucleus (SAMIA in 1938) and after them, there were Russians and Chinese. The first Copper Smelting Plant in Albania opened in Rubik because it had resources of high-quality copper with silver and gold in it. Most of the copper mines and establishments in Albania were opened after the 1950s and 1960s, which supplied the Copper Smelting Plant in Rubik and the Pyrometallurgical Plant in Laç. Gold and silver production in Rubiku copper smelting plant has been high for almost 20 years and has supported the economy of the country. The collaboration with China from 1960 to 1978 was very important for Albanian economy, especially for Metallurgical industry, which is shown in the growth of gold and silver in this period. This growth continued until 1990 when the communist regime declined, and many former industrial establishments were destroyed and robbed by the people (Graph 1, Graph 2).

Laçi and Rubik are two small towns in Albania that were created and expanded after the establishment of industrial activities in them. From small rural settlements (especially Rubik) they grew in population and size to become important industrial towns (although their modest industry and urban areas, Laçi and Rubik were declared towns according to the administrative organization of the territory of Albania during communist regime). Laçi was ranked the second most important city in Northern Albania by size, population, and economic importance.

The development of industry had its impact mostly on the main economic activities of these two towns which were transformed from rural settlements, focusing on agriculture and artisan activity, into urban areas (small industrial towns) offering industrial, administrative, educational, social and cultural activities and functions. The opening of the Chemical and Technological High School in Laç and Metallurgical High School in Rubik contributed highly in the educational and professional level of their population. As mentioned earlier in this paper Albania had a lack of professionals and educated people and the investments in these two schools related to the professions of the industry in these areas would provide specialists for the future.

The development of industry in Lac and Rubik had a high demand for workers which were brought from the near villages or other cities of Albania. In the first years after the industrial establishments opened, the population of Rubik was very low, with only six houses (48 inhabitants) in 1939 (Picaku, 2012), it reached 822 in 1959 and then 5000 in 1979. In Laç the population changed from 500 in 1959 to 9500 in 1979, reaching almost 30,000 by the end of the 1990s (Laçi, 2008). The direct impact of the industry in population size is more evident in Rubik which almost stopped growing after 1990, and in the period 2001 to 2014 has been growing with only 1147 inhabitants or 88 inhabitants per year (Table 1.). This pattern is also seen in Laç where the population growth rate is getting lower every year. Another impact of the industry on population was also the change in its age and gender structure. The working force brought to these towns was relatively young and mostly men working in mine and heavy industry sector. In Rubik, the gender structure changed in favor of men, but in Laç the gender structure was more equilibrated as it has also developed light industry and other economic sectors.

The urbanization of Laç and Rubik was very fast after the investments in the industry. The working population needed apartments and other services and recreational buildings. Many apartments with 5-6 floors were built for the workers and their families. In Laç was built the Palace of Culture, Town's Library, some sports facilities for children and youths, some recreational facilities, kinder gardens, schools, etc. Rubik had fewer buildings as its population was not as big as in Laç.

Changes also happened in the economic and employment structure of the towns. In Laçi town the population had many other options to work apart from the industrial sector, which in Rubik was not possible as the other economic sectors were not as developed. In Laç, almost in each family, one member was employed in the industrial sector and one in another economic sector, mostly in service and education while in Rubik, most of the population was employed in the industrial sector and only a few in agriculture and other sectors. The employment in industry increased the welfare of the population in both towns as it was one of the most paid sectors during the communist regime, especially the heavy industry. The difference between the families which had at least one employed in the industry with the others who did not have any was noticeable. Actually, in both towns, the employment in the industry is very low compared with other sectors. (Map 5.)

The Decline Of Industry And Its Impact On The Socio-Economic Development Of Laçi And Rubik After The Year 1990 
The decline of the communist regime in 1990 was the beginning of many changes in the economic and social life of the people living in Albania. The industry and many other economic activities experience different problems and changes to adapt to the new democratic system established in Albania. The heavy industry, which had had a leading role during the communist period, was the first to suffer the changes resulting in the closing of many mines throughout Albania. The state investments to the industry were very low and not sufficient to keep people working. Most of the heavy industry establishments were closed in the early years of the 1990s and were damaged by the local people. Some chimneys of the Rubik Copper Pant were demolished and then sold for scrap. The same fate also had the Copper Refinery plant which could have been kept in function for many other years. In Laç, the Superphosphate Plant continued its production until 1993 when all the remaining reserves of phosphorus finished. Also, the acid factories were closed and then damaged causing many environmental problems.

The industry in Rubik was experiencing difficulties to continue functioning also because the raw material was impoverished too much and the technology was very old, otherwise in Laç the technology was better, but still it needed some improvements. Nowadays the industry in these towns is not in function, and the possibilities to reactivate it are scarce as most of the ex-industrial buildings are very damaged and destroyed after so many years without working. The most damaged one, causing much environmental pollution is the Chemical Metallurgical Combine in Lac. In last years have been many attempts from the local people to steal the last remaining of the Combine and three persons have even lost their lives.

The ex-industrial areas have been transformed and reused differently in the Albanian towns. In some of them, the population has reused part of industrial buildings to establish small enterprises, some for housing, small shops, etc. Other ex-industrial areas where the contamination and pollution from the industrial activity is high aren't used for any new function. In Laç and Rubik the situation of these areas is very bad and a source of environmental pollution, but this has not prevented the population to built houses and small businesses near them. These families throw their waste in the surrounding areas increasing the pollution of land, water, and air.

The economic function of Laçi and Rubiku changed again after the year 1990, and from industrial towns now they are more focused in the service sector and agriculture. The production capacity of small enterprises opened lately in Laç cannot be compared with the one before 1990. The population is focused now mostly in the service sector, especially religious and environmental tourism.

Laçi has always been more developed than Rubik and continues to have an important role in the region, especially after the last administrative organization of the territory of Albania it is the main city of Kurbini Municipality.

\section{Negative Impact Of The Industry On The Environment Of Lac And Rubik}

Despite its positive impact on the economy and population life, the development of industry in Laç and Rubik had also negative impacts on the environment and population health. The location of the industrial plants in the suburban areas was not a good decision for the environment of the industrial towns and the population in general.

The industrial activity in Laç and Rubik discharged poisonous gases to the atmosphere which were transported by the winds toward the towns exposing most of the population to this pollution. The direction of the winds was a key factor which should have been taken into account for the right location of the industrial plants and establishments. In Laç, where the prevailing southwestern winds during the winter season and eastern ones during the summer season shifted away poisonous gases released from industrial facilities, particularly from the Superphosphate Plant and the copper enrichment to the town. They should have been located in the other part of Laçi town to avoid industrial gases. In Rubik, this problem was not very evident and frequent as in Laç. The air pollution in these towns has caused many health problems, especially respiratory and skin diseases, not only for the population working in the industry but also for the other residents which were not in direct contact with the industrial activity. The areas have also suffered quite often acid rain which has damaged the plants and agriculture crops.

The rapid growth of the population in the first years of the industrialization, which continued, had its impact on the increase of the urban waste as well as water and air pollution. This environmental problem is still present and untreated properly in Laç and Rubik where there are only few garbage bins around the towns, and the wastes are collected in landfills near them. The urban waste and the inerts of the ex-industrial buildings augment the pollution of the land, water, and air. Especially, highly polluted from the industrial activity is Mati River which is also the most important one for the region where these two 
towns are situated. It has been estimated a reduction of different species breeding in the river and plants due to high levels of heavy metals and BOD in water. (Table $2,3$. )

The industry had a negative impact also on the land and its uses. Most of the land that once was considered agricultural was then used for industrial buildings and for the construction of the apartments for the workers brought from other villages and towns to work in the industry (Table 4.). The expansion of Laçi town especially restricted the agricultural land. After the use for industrial activity, most of this land can no longer gain its previous fertility to be reused for agriculture (Table 5.)

\section{The Importance Of Functional Transformation Of Laçi And Rubik's Ex-Industrial Areas}

The development of sustainable industry is one of the 17 objectives of the UN, especially in the developing countries as Albania. The ex-industrial areas not in function are widely known as Brownfields, and in Albania, there are many of them. These areas endanger human health, impede economic development, reduce the value of the surrounding lands, etc. Their functional transformation has economic, social, environmental benefits.

Appropriate reuse or functional transformation of Laçi and Rubik's ex-industrial areas will convert them from heavily polluted and abandoned areas into areas of recreation and leisure. This process is not easy and requires the appropriate human and financial resources. In Laç and Rubik the process may be very difficult because: their ex-industrial areas are very polluted; there is a lack of legal basis for their development as well as regulations on how to develop and support regulatory activities; there is also a lack of researchers and national strategy in these areas; ex-industrial buildings in both towns are very damaged.

Ex-industrial areas and objects have been mostly reused for other industrial functions, for companies' main offices, shopping and entertainment centers, shelters for homeless people, etc. In some other countries, they have been preserved as industrial heritage and used for tourism and research proposes. The Albanian government should take into consideration other countries experience and compile a national strategy on ex-industrial areas functional transformation which should include: a. Identification, mapping and inventorying of ex-industrial areas; b. Classification and valuation of their social, economic and environmental potential for development; c. Recovering and adaptive reuse. As one of the main issues in dealing with these areas in Albania, it is the lack of financial resources to clean them following the appropriate procedures, the government can invite the private companies and businesses to invest by offering them lower taxes for a certain period, low land price, etc. The local government and community have their important role and have to be involved in the whole process from the preparation phase to the implementation of the strategy.

The ex-industrial areas in Laç and Rubik are very small compared with similar areas around the world, and the most appropriate reuse would be transforming them in recreational and industrial heritage areas going through some important steps:

Cleaning the ex-industrial areas and their surrounding from the solid and liquid pollution in land, water, and air;

Restoration of the remaining walls of the ex-industrial buildings, which should match the original style. It is also important to fence in the ex-industrial area to protect their territory from local people who can damage the existing buildings or build houses very near or inside these areas.

After the ex-industrial areas are restored and transformed into recreational areas, it is necessary to put signs near them and around both towns to give directions for people who want to visit and spend some time there. These signs should be in Albanian and English to attract also foreigner visitors. Inside the recreational areas, there should be other signs and tables with information and pictures about their former use and importance. There can also be specialized guides to explain the previous use of these areas and other necessary information about them.

Planting trees, the creation of green spaces for children's entertainment, putting some benches around the area for the visitors, the opening of small cafes and shops (souvenir shops with artisan works from both towns), etc. would help in the fulfillment of the recreational function of these areas.

Laçi town is bigger than Rubik, and it has more visitors, especially during May and June, to the Shen Ndoit church. It would be more suitable to build also a parking lot in its ex-industrial areas to reduce the traffic jam during the pilgrimage days and summer. 
The local governments of both towns through following these suggestions and also getting experience from other towns inside or outside Albania can achieve the functional transformation of these areas and all the other benefits: economic, social and environmental. Two 3D maps were prepared in Arc View 10.3 to have a visual image for the propositions given to transform the ex-industrial areas (Map 6,7). These two maps provide a general outline of how these two areas can be transformed.

The transformation of the studied areas as well of the other ex-industrial areas in Albania which are a permanent source of environmental pollution should start as soon as possible and should be in the program of every central and local government.

\section{References}

[1] Albanian Academy of Science (1990). Gjeografia Fizike e Shqipërisë I (Physical Geography of Albania I). Tirana, Albania

[2] District of Lezha. INSTAT Offices.

[3] Doka, Dh. (2005). Zhvillime Socio-Ekonomike dhe Rajonale të Shqipërisë pas vitit 1990 (Social economic developments in Albania after the year 1990). Postdam, Germany. Industrial Heritage in Albania and the Opportunities for Regeneration and Adaptive Re-Use, 2015.

[4] Institution for extracting and processing technology for minerals. (2006). Strategjia e Zhvillimt të Industrisë Minerare (Mining Industry Development Strategy). Tiranë, Albania.

[5] Industrial Heritage in Albania and the Opportunities for Regeneration and Adaptive Re-Use, 2015

[6] Kiss, E. (2002). Restructuring in the Industrial Areas of Budapest in the Period of Transition. Urban Studies.

[7] Kurbini Municipality, Civil Registry Office.

[8] Laçi, S. (2008). Kurbini në rrjedhën e industrializimit, arritje, dështime, mundësi (Kurbini in the course of industrialization, achievements, failures and opportunities). Albanological studies journal 2008/4.

[9] Miho, A. (2012). Lumenjtë e jetës (The Rivers of Life) www.ekolevizja.org.

[10] Mirdita Municipality, Civil Registry Office.

[11] Mirdita, Periodic Journal for Art and Culture, Nr.13, Mirdita, Albania: Mirgeeralb, pg. 52.

[12] Picaku, N. (2012). Rubiku shtëpia jonë (Rubiku our home), Tirana, Albania: pg 248

[13] Pulaj, B. (2002). Mirdita Njohuri për Vendlidjen (Mirdita, Knowledge for the hometown). Tiranë, Albania. pg. 22

[14] REC Albania (2015). Mjedisi Sot (The Environment Today). Tirana, Albania.

[15] Report of Grontmij, Carl Bro and European Union CARDS 2006. (2010). pg. 38-39.

[16] SARMa. (2010). Mbi konsideratat mjedisore dhe sociale për zhvillim e qëndrueshëm të minierave (Environmental and social considerations for sustainable mining development).

[17] Sheme. S. (2012), Gjeografia e Industrisë (Industrial Geography), Tiranë, Albania: pg. 206-208.

[18] Tusha, N. (2006). Mirdita (Atlas Gjeografiko-Historik) (Mirdita. Geographic and Historic Atlas). Tirana, Albania: pg. 10-11.

[19] UNEP (2000). Balkans Post-Conflict Environmental Assessment Albania Analytical Results of UNEP Field Samples from Industrial Hot Spots. pg. 14-15.

[20] UNEP. (2000). Vlerësimi Mjedisor në Shqipëri pas Konflikti, Zvicërr 2000, page 36-37.

[21] www.ecy.wa.gov.

[22] www.epa.gov.

[23] www.world-food.net, Journal of food Agriculture \& Environment July-October 2013. 


\section{Tables}

Table 1. Changes in population number of Laç and Rubik, 1939-2014

\begin{tabular}{|l|l|l|l|l|l|l|l|}
\hline Town name Year & 1939 & 1959 & 1979 & 2001 & 2011 & 2013 & 2014 \\
\hline Laç & No data & 500 & 9500 & 19424 & 17086 & 30745 & 29422 \\
\hline Rubik & 48 & 844 & 5000 & 6842 & 4454 & 8143 & 7989 \\
\hline
\end{tabular}

Source: Civil Registry Offices in Laç and Rubik

Table 2. The presence of heavy metals in Laçi and Rubiku waters

\begin{tabular}{|l|l|l|l|l|}
\hline Heavy metals in water & $\mathrm{Cu}$ & $\mathrm{Si}$ & $\mathrm{Cd}$ & $\mathrm{Cr}$ \\
\hline Laç & $26.36 \mathrm{mg} / \mathrm{I}$ & $8.5 \mathrm{mg} / \mathrm{l}$ & $0.011 \mathrm{mg} / \mathrm{l}$ & $0.011 \mathrm{mg} / \mathrm{I}$ \\
\hline Rubik & $22,46 \mathrm{mg} / \mathrm{I}$ & - & $0.012 \mathrm{mg} / \mathrm{I}$ & $0.04 \mathrm{mg} / \mathrm{I}$ \\
\hline
\end{tabular}

Source: UNEP, 2000.

Table 3. The Ph and BOD in Mati River

\begin{tabular}{|l|l|l|l|l|}
\hline River & Station & Date & Ph & BOD \\
\hline Mati & Miloti & 20.09 .2002 & 8.35 & 1.05 \\
\hline Mati & Miloti & 19.06 .2003 & 8.46 & 3.70 \\
\hline Mati & Miloti & 03.11 .2004 & 8.61 & 4.80 \\
\hline Mati & Miloti & 23.08 .2005 & 7.92 & 1.45 \\
\hline Mati & Miloti & 20.10 .2006 & 8.45 & 0.45 \\
\hline Mati & Miloti & 02.11 .2007 & 8.19 & 2.0 \\
\hline Mati & Miloti & 01.09 .2008 & 7.93 & 1.9 \\
\hline
\end{tabular}

Source: UNEP, 2000.

Table 4. The presence of heavy metals in Laçi and Rubiku land

\begin{tabular}{|l|l|l|l|l|}
\hline Heavy metals in land & $\mathrm{Cu}$ & $\mathrm{Si}$ & $\mathrm{Pb}$ & $\mathrm{Cr}$ \\
\hline Laç & $1,422 \mathrm{mg} / \mathrm{kg}$ & $526 \mathrm{mg} / \mathrm{kg}$ & $43 \mathrm{mg} / \mathrm{kg}$ & - \\
\hline Rubik & $1,696 \mathrm{mg} / \mathrm{kg}$ & - & $99 \mathrm{mg} / \mathrm{kg}$ & $492 \mathrm{mg} / \mathrm{kg}$ \\
\hline
\end{tabular}

Source: UNEP, 2000.

Table 5. Main polluted industrial and ex-industrial areas in Albania

\begin{tabular}{|ll|}
\hline $\mathbf{N r}$ & Main polluted industrial and ex-industrial areas in Albania \\
\hline $\mathbf{1}$ & Vlora area: Polluted with $\mathrm{Hg}$ and $\mathrm{PCB}$ \\
\hline $\mathbf{2}$ & Fieri area: Polluted with $\mathrm{As}$ \\
\hline $\mathbf{3}$ & Porto Romano areas: Polluted with pesticides \\
\hline $\mathbf{4}$ & $\begin{array}{l}\text { Elbasani area: Polluted by dangerous gases, discharge of industrial water in rivers, } \\
\text { hazardous waste, slag. }\end{array}$ \\
\hline $\mathbf{5}$ & Laç, Kurbin: Polluted from Copper Melting Plant \\
\hline $\mathbf{6}$ & Elbasan: Smelting plant of Cr and Ni \\
\hline 7 & Laçi area: Polluted with fertilizers and acids \\
\hline $\mathbf{8}$ & Rubiku area: Polluted by the copper industry wastes \\
\hline $\mathbf{9}$ & Ballshi area: Polluted by petroleum Industry \\
\hline $\mathbf{1 0}$ & Puka area: Polluted by Copper Industry \\
\hline
\end{tabular}

Source: SARMa, 2010 


\section{Graphics}

Graph 1. Gold production in Rubik 1968-1990 (in kilogram)

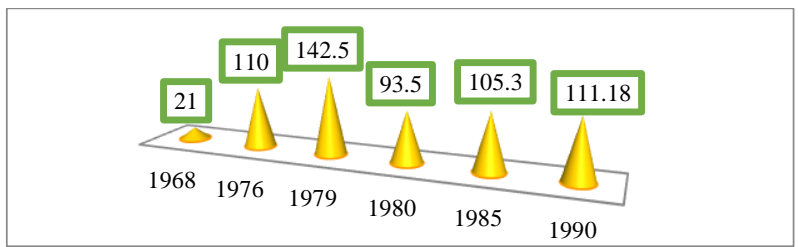

Graph 2. Silver production in Rubik 1968-1990 (in kilogram)

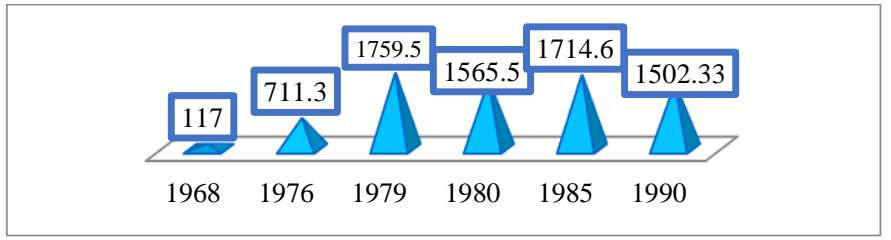

\section{Maps}

Map 1. Administrative map of District of Lezha

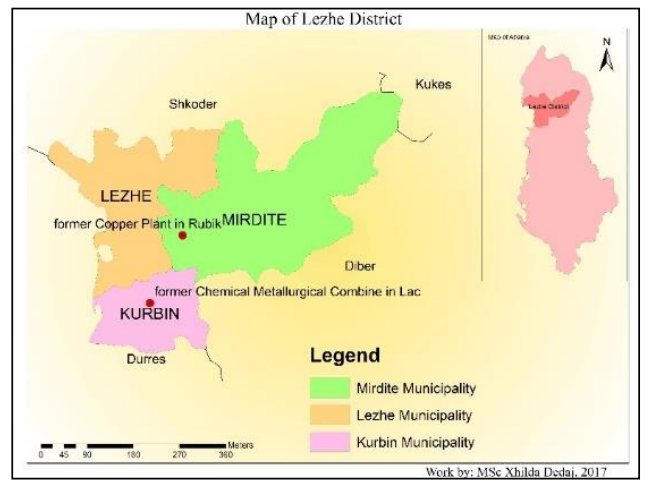

Map 2. Administrative map of Laçi town and the location of ex-industrial area

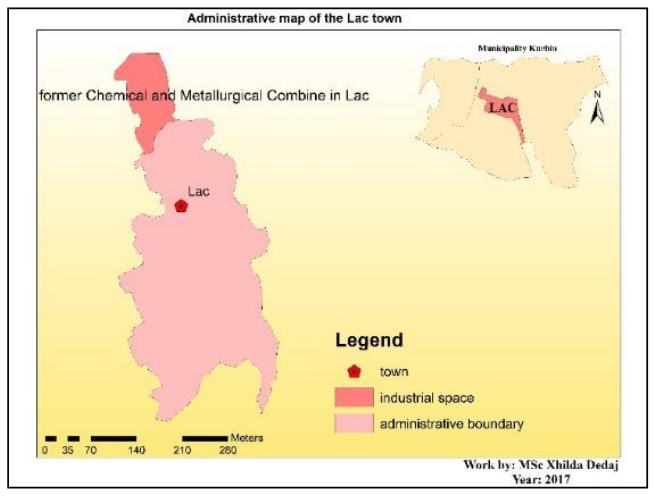


Map 3. Administrative map of Rubiku town and the Map 4. Copper Reserves in Mirdita till 1990 location of ex-industrial area
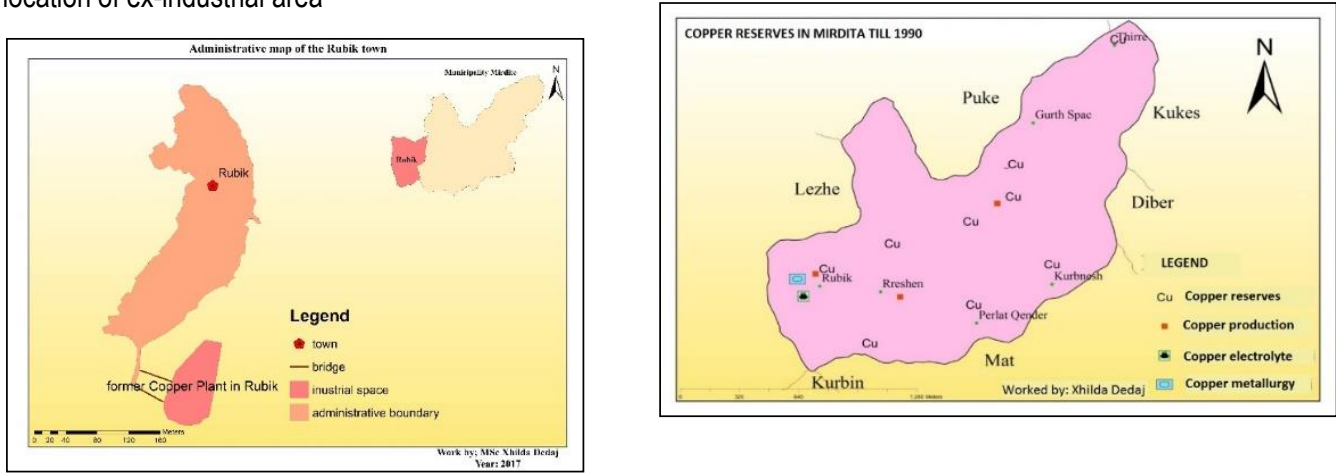

Map 5. The percent of population employed in service sector in Laç and Rubik, 2014

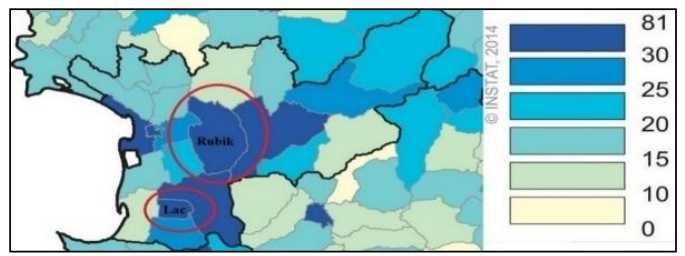

Source: INSTAT, 2014

Map 6. The functional transformation of former Chemical and Metallurgical Combine in Laç (proposition)

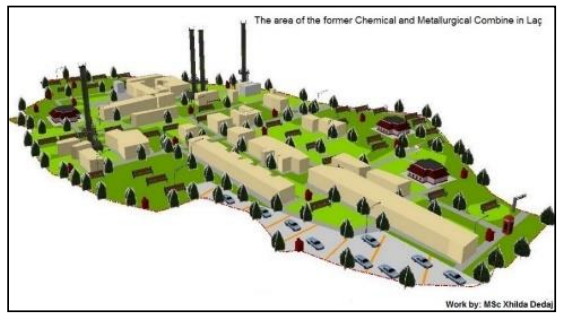

Map 7. The functional transformation of former Chemical and Metallurgical Combine in Rubik (proposition)

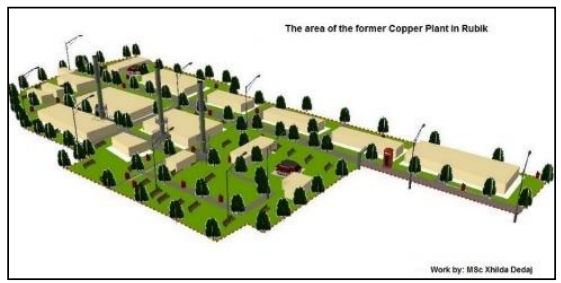

